\title{
IUGS 1982 FINANCIAL STATEMENT, 1983 BUDGET
}

\author{
Statement of Receipts and Payments for the Year Ended December 31, 1982, (See Note 1)
}

\section{RECEIPTS}

- UNESCO contracts and receipts for IGCP projects (See Note 2)

- Membership dues (See Note 3)

Special grants and contracts (See Note 4)

- Allocation from UNESCO subvention to ICSU (See Note 5)

- Income from publications:

- EPISODES subscriptions and related income

- Royalties, IUJGS Publications sales

- Bank interest and gain on exchange

- Miscellaneous receipts (See Note 6)

\section{PAYMENTS}

Scientific activities

- IGCP (See Note 7)

- IGCP: IUGS supplemental allocations (See Note 8)

- IUGS Commissions, Committees (See Schedule A and Note 9)

- Payments on special contracts

- Research Development Program (See Note 10)

- Symposia

- IUGS Affiliated Organizations (See Schedule B and Note 9)

- Inter-Union Commissions (Lithosphere program)

- Representation at scientific meetings

- Routine meetings

- 1981: Executive Committee meeting, Accra

- 1982: Executive Committee meeting, Bonn

- 1983: Executive Committee meeting, Bangkok

Publications

- EPISODES printing and related costs (See Note 11)

- Other IUGS publications: printing costs

- Promotion and displays for publications

- Miscellaneous costs related to publications

- Administrative expenses

- Salaries and related charges (See Note 11)

- Operating costs and supplies

- Miscellaneous charges

- Bank charges, loss on exchange

Payments to ICSU

- 1981 membership dues

- Contribution to Committee on Teaching of Science

- Dues to ICSU Abstracting Board

STATUS OF ACCOUNTS (As of December 31, 1982)

Ottawa - (Episodes account)

President's account (Bonn)

Past President's account (Zurich)

Zurich - Operations account

" - Reserve account

Secretary General's account (Paris)

Treasurer's account Reston

Reserve account Reston

\section{SUMMARY}

Accounts receivable December 31

Accounts payable on December 31

Difference

Accumulated balance at January 1

Plus excess of receipts over expenditures

Less excess of expenditure over income

Accumulated balance at December 31

Plus difference between accounts receivable and payable

NET FINANCIAL ASSETS AT DECEMBER 31
1982

128836

161956

43600

9600

20532

2829

24

TOTAL $\quad \frac{63}{367440}$

(\$U.S.)

157484

157483

37469

11366

16602

4637

5878

10515

401434

138700

15100

42330

11923

6703

18500

17050

10000

15159

11156

1786

126900

7000

58650

34669

4656

27200

10000

8626

Budget

for

1983

(\$U.S.)

140000

160000

35000

11665

20000

5500

6000

500

378665

140000

10000

59000

26000

5000

30000

10000

4000

12130

54065

14557

23195
1718
4402

3112

1135

22078

1651

1229

21029

15502

3495

2503

2240

400

360

TOTAL $\lcm{386 \quad 122}$

3597

400

360

$36 \overline{144}$

18000

23500

2000

3000

1305

21500

16000

3500

1500

3600

400

360

378665
8882

1105

2108

13589

449

18629

25000

TOTAL

62444

102339

38550

63789

81125

18681

62444

63789

126233
62444

46261 
Note 1: This Statement has been prepared by the Treasurer in accordance with the Statutes and Bylaws of the Union. Receipts and payments have been recorded in the books of account in the currency used by each bank account and then converted to \$U.S. at year-end, based on official ICSU rates of exchange for December 31, 1982.

The Statements do not reflect:

a) costs borne by member countries in support of activities and operations of the Union;

b) details of unpaid accounts receivable or payable by the Union as at December 31, 1982.

In order to provide a basis for comparison, both the 1981 receipts and payments and the estimated income and projected expenditures for 1983 (under Budget for 1983) have been included.

Adjustments have been made in categories of expenditures for 1981 as shown in Episodes, vol.1982, no.3, p.62 to correspond with categories shown for 1982 and 1983.

Note 2: IGCP receipts come from one source: contract funds from Unesco allocated to IGCP projects. Total payments to IGCP projects, however, include the following: the contract funds from Unesco, plus an annual contribution from IUGS which in 1982 totalled $\$ 7000.1981$ receipts figure includes $\$ 22286$ received for IGCP projects funded in 1980 , while the 1982 figure includes $\$ 26984$ received from projects funded in 1981 (that is, final payments on contracts initiated in 1981). 1983 estimates assume that all amounts allocated by Unesco for IGCP projects in 1983 plus carry-over allocations for 1982 are received by IUGS during the year.

Note 3: Member countries pay annual contributions according to their selected category of membership as outlined in the following table:

$\begin{array}{llrrrrrrr}\begin{array}{l}\text { Category } \\ \text { Units* of }\end{array} & 1 & 2 & 3 & 4 & 5 & 6 & 7 & 8 \\ \text { Contribution } & 1 & 2 & 4 & 7 & 12 & 20 & 35 & 70\end{array}$

(*ne unit of contribution was valued at U.S. $\$ 300$ as of July 10, 1980)

The 1982 receipts figure includes $\$ 22483$ paid in 1982 covering membership dues for prior years and $\$ 300$ paid in advance for 1983 .

Note 4: Receipts from special grants and contracts during 1982 included:

- COGEODATA contract with

CCOP/ESCAP No. CAP/81/150/

CON-01

Supplemental grant from ICSU

under Unesco contract 250.298

Grant from IDRC Ottawa, Canada

to help support IUGS Workshop

on Petroleum Resources Assessment

Techniques

Contribution from East-West Center

Honolulu, Hawaii, to help support

IUGS Workshop on Petroleum Resources

Assessment Techniques

Contribution from U.S. National

Academy of Sciences for communica-

tion expenses

TOTAL

Note 5: IUGS received \$11 366 from ICSU in 1982 as an apportioned amount of the Unesco subvention to ICSU. IUGS pays an annual subvention to ICSU based on $2.5 \%$ of IUGS membership fees. IUGS paid a fixed annual contribution of $\$ 10000$ to ICG during its tenyear existence, and is providing a similar fee of $\$ 10000$ to ICL together with a supplemental allocation under the Rescarch Development Program which, in 1982, was $\$ 4000$ (See Note 9).

Note 6: Funds mostly withdrawn from Treasurer's account prior to December 31, 1982, to cover expenses of IUGS seminar and Executive Committee meeting in Bangkok, but redeposited in February 1983 as excess to the requirement for these mectings.

Note 7: Funds transferred to IGCP project leaders for IGCP project activities carried out in 1982. Some 1982 allocations were carried over into 1983 for project activities authorized, but not carried out, in 1982 .

Note 8: IUGS provided supplemental funds totalling $\$ 7000$ to the following IGCP projects in 1982 .

$\begin{array}{ll}\text { IGCP Project } 120 & 2000 \\ \text { IGCP Project } 146 & 2000 \\ \text { IGCP Project } 160 & 1000 \\ \text { IGCP Project } 161 & 2000 \\ & \$ 7000\end{array}$

IGCP Project 16

Note 9: Total payments to IUGS Commissions, Committees and Advisory Boards in $1982(\$ 58650)$ in cluded $\$ 3400$ for allocations made in 1981. Payments totalling $\$ 55250$ for allocations made in 1982 were as shown in Schedule A.

Total payments to IUGS Affiliated Organizations in $1982(\$ 27200)$ included $\$ 2500$ for allocations made in 1981. Payments totalling $\$ 24700$ for allocations made in 1982 were as shown in Schedule $B$.

Note I0: 1982 expenditures for the International Research Development Program (IDRP) included $\$ 17669$ for the seminar on Petroleum Resources Assessment Techniques held in Honolulu (with contributions from the IDRC and the East-West Center as shown in Note 4); $\$ 5000$ for research in the Pannonian Basin; $\$ 8000$ to supplement COGEODATA activities in Africa and South America, and $\$ 4000$ to supplement the allocation to the ILP.

Note 11: In 1981 salary costs for Episodes were included under

"Episodes printing and related costs", whereas in 1982 and 1983 these salary costs are shown under "salaries and related charges."

\section{SCHEDULE A}

1982 PAYMENTS: COMMISSIONS, COMMITTEES

Commission on Experimental Petrology $\quad$ (\$U.S.)

Commission on Geological Documentation 1000

Commission on Geology Teaching

Geological Sciences (INHIGEO)

Commission for Marine Geology

Commission on Storage, Automati

Processing and Retrieval of

Geological Data (COGEODATA)

Commission on Systematics in Petrology

Commission on Tectonics

Commission on Stratigraphy

Subcommission on Geochronology

Subcommission on Precambrian

Stratigraphy

Precambrian-Cambrian Boundary

Working Group

Subcommission on Precambrian

Stratigraphy

Subcommission on the Cambrian-

Ordovician Boundary

Subcommission on Ordovician

Stratigraphy

Subcommission on Silurian

Stratigraphy

Subcommission on Devonian

Stratigraphy

Subcommission on the Devonian-

Carboniferous Boundary

Subcommission on Carboniferous

Stratigraphy

Subcommission on Permian

Stratigraphy

Subcommission on Triassic

Stratigraphy

Subcommission on Jurassic

Stratigraphy

1000
7000

7500

1500

2000

3870
Jurassic Cretaceous Boundary

Subcommission on Cretaceous Stratigraphy

Palaeogene/Neogene Boundary

Working Group

Subcommission on Paleogene

Stratigraphy

Subcommission on Neogene

Stratigraphy

Subcommission on Pacific

Neogene Stratigraphy

Subcommission on Mediterranean

Neogene Stratigraphy

Working Group on Neogene-Quaternary

Boundary

Subcommission on Quaternary

Stratigraphy

Subcommission on Gondwana

Stratigraphy

Advisory Committee on Comparative

Planetology

Advisory Board for Publications

Ad Hoc Committee on Sedimentology

TOTAL

700

1500

1850

350

250

100

1250

1000

200

2500

2000

2500

$\$ 55250$

SCHEDULE B

1982 PAYMENTS: AFFILIATED ORGANIZATIONS

AGID
CGMW
ASGA
IAEG
IAGOD
IAG
IAH
IAMG
IAP
ICP
IPA
SGA
GSA

(\$U.S.)

7000

4000

TOTAL $\$ 24700$

SCHEDULE A-83

983 BUDGET: COMMISSIONS, COMMITTEES

Commission on Geology Teaching

(SU.S.)

INHIGEO

Commission for Marine Geology

COGEODATA

Commission on Systematics in Petrology

on Tectonics

Commission on Stratigraphy

Advisory Board for Publications

Ad Hoc Committee on Sedimentology

Contingent

TOTAL $\$ 58200$
SCHEDULE B-83

1983 BUDGET: AFFILIATED ASSOCIATIONS

$A G A$

AGID

ASGA

CGMW

GSA

IAEG

IAGC,

$\mathrm{IAGON}$

$\mathrm{IAH}$

IAMG

IAP

IPA

INQUA

SGA

Contingent
150.5$.

1000

10000

1000

3000

4500

1000

500

000

1300

2000

750

I 500 